\section{BamHI RFLP at the GLUT3 locus}

P.Patel ${ }^{2}$, G.I.Bell ${ }^{1}$, R.C.Turner and

\section{J.S.Wainscoat ${ }^{2}$}

Diabetes Research Laboratories, Nuffield

Department of Clinical Medicine, Radcliffe

Infirmary, Oxford, UK, ${ }^{1}$ Howard Hughes

Medical Institute, University of Chicago, 920 East

58th Street, Chicago, IL 60637, USA and

${ }^{2}$ Department of Haematology, John Radcliffe

Hospital, Headington, Oxford OX3 9DU, UK

Source and Description: pBS/MGT3 is a cDNA clone containing a $2.6 \mathrm{~kb}$ SalI insert which encodes human fetal skeletal glucose transporter-like protein.

Polymorphism: BamHI identifies a two allele polymorphism with fragments of $5.5 \mathrm{~kb}$ (allele A) and $5.0 \mathrm{~kb}$ (allele B) and detects four invariant bands of $24 \mathrm{~kb}, 23 \mathrm{~kb}, 14 \mathrm{~kb}$ and $7 \mathrm{~kb}$.

Frequency: Studied in 16 normal unrelated European Caucasian individuals.

Allele $\mathrm{A}=0.6 \mathrm{~kb}$

Allele $\mathrm{B}=0.4 \mathrm{~kb}$

Chromosomal Localization: Assigned to chromosome 12p13.3 using a panel of mouse-human somatic cell hybrids and by in situ hybridization to metaphase chromosomes (1).

Mendelian Inheritance: Co-dominant segregation observed in 2 families.

Probe Availability: Contact G.I.Bell.

Acknowledgement: This work is supported by a grant from the Medical Research Council (UK).

Reference: 1) Kayano,T. et al.(1988) J. Biol. Chem. 263, $15245-15248$.

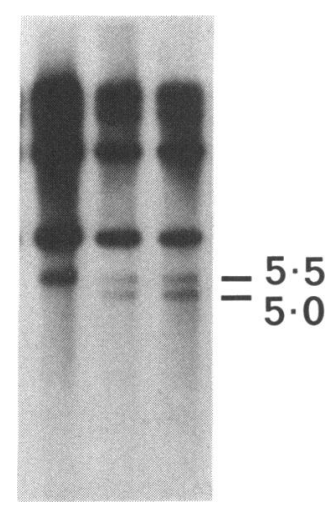

\section{TG repeat polymorphism at the D21S167 locus}

\author{
Z.Guo, V.Sharma, D.Patterson ${ }^{1}$ and M.Litt* \\ Oregon Health Sciences University, Portland, OR \\ 97201 and ${ }^{1}$ Eleanor Roosevelt Institute for \\ Cancer Research, Denver, CO 80206, USA
}

Source and Description: Cosmid ICRFc102A0322 was from a flow-sorted human chromosome 21-specific library. DNA sequences flanking a $(\mathrm{GT})_{19}$ repeat within this cosmid (EMBL accession number X52289) were used to design PCR primers.

PCR Primers:

(\# 112)-5'-TCCTTCCATGTACTCTGCA-3'
(\# 113)-5'-TGCCCTGAAGCACATGTGT-3'

Polymorphism: Allelic fragments were resolved on DNA sequencing gels. Lengths of allelic fragments (nt) were: $\mathrm{A} 1=$ $156, \mathrm{~A} 2=158, \mathrm{~A} 3=160, \mathrm{~A} 4=162, \mathrm{~A} 5=164, \mathrm{~A} 6=166$, $\mathrm{A} 8=172, \mathrm{~A} 9=174, \mathrm{~A} 10=176, \mathrm{~A} 11=178, \mathrm{~A} 12=180$, $\mathrm{A} 13=182$.

Frequencies: Allele frequencies in 33 unrelated European Caucasians: $\mathrm{A} 1=.030, \mathrm{~A} 2=.272, \mathrm{~A} 3=288, \mathrm{~A} 4=.061$, $\mathrm{A} 5=.030, \mathrm{~A} 6=.030, \mathrm{~A} 7=.061, \mathrm{~A} 8=.061, \mathrm{~A} 9=.030$, $\mathrm{A} 10=.061, \mathrm{~A} 11=.045, \mathrm{~A} 12=.015, \mathrm{~A} 13=.015 ; \mathrm{PIC}=$ 0.80 .

Chromosomal Localization and Mendelian Inheritance: PCR of genomic DNAs from a somatic cell hybrid panel (1) indicated localization to 21q22.2. Linkage analysis in $3 \mathrm{CEPH}$ families showed no recombination in 21 informative phase-known meioses with D21S15 (previously localized to 21q22.2 (1)), giving a maximum LOD score of 6.3 at theta $=0$. Mendelian inheritance was observed in all cases.

PCR Conditions: We carry out PCR as in reference (2) using an annealing temperature of $56^{\circ} \mathrm{C}$.

Acknowledgements: This work was supported by Grants GM-32500 and HD17449 from the National Institutes of Health. We thank H.Lehrach for providing us with ICRFc102A0322.

References: 1) Gardiner,K., Horisberger,M., Kraus,J., Tantravahi,U., Korenberg,J., Rao,V., Reddy,S. and Patterson,D. (1990) EMBO J. 9, 25-34. 2) Luty,J.A., Guo,Z., Willard,H.F., Ledbetter,D.H., Ledbetter,S. and Litt,M. (1990) Am. J. Hum. Genet. 46, 776-783.

\footnotetext{
* To whom correspondence should be addressed
} 